\title{
Rainfall Variability in Rayalaseema Region of Andhra Pradesh
}

\author{
Kanaparthi Narasimhareddy*, Abhishek James and Shweta Gautam \\ Department of Environmental sciences and Natural Resource Management, \\ Sam Higginbottom University of Agriculture, Technology and Sciences, \\ Prayagraj, Uttar Pradesh, India \\ *Corresponding author
}

\begin{tabular}{|c|c|}
\hline & A B S T RA C T \\
\hline Keywords & \multirow{10}{*}{$\begin{array}{l}\text { The present research investigation was undertaken to work out the rainfall } \\
\text { variability of all districts of Rayalaseema in Andhra Pradesh. The meteorological } \\
\text { data of rainfall required for the rainfall variability analysis was collected during } \\
1989-2018 \text { from Central Research Institute for Dryland Agriculture, Hyderabad. } \\
\text { The coefficient of variation and standard deviation for monthly and annual rainfall } \\
\text { were also computed for all the districts. The normal onset of monsoon over } \\
\text { different districts of Rayalaseema is between June to October. Results showed that } \\
\text { the annual rainfall is higher at Chittor district followed by Kadapa and Kurnool. } \\
\text { The mean annual rainfall is lowest at Ananthpur. When the CV for the annual } \\
\text { rainfall or rainfall variability was examined, it was found be the least at Kurnool } \\
\text { followed by Chittor and Kadapa. At Ananthpur it was the highest. }\end{array}$} \\
\hline Rainfall, & \\
\hline Variability, & \\
\hline Rayalaseema, & \\
\hline Monsoon & \\
\hline Article Info & \\
\hline & \\
\hline 04 November 2020 & \\
\hline Available Online: & \\
\hline & \\
\hline
\end{tabular}

\section{Introduction}

The rainfall is an important and governing factor in the planning and operation strategies of any agricultural programme for any given area. As such, proper and specific information about the rainfall distribution pattern over a period for a particular place is quite essential for proper and optimal planning of requisite irrigation system and cropping pattern. The major share of conjunctive water-need of the country during entire calendar year is met by the rainfall, which occurs in the monsoon period. Rainfall is one of the most important natural resource input to crop production in tropical region. Out of 189.54 million ha
(1996- 97) gross cropped area of the country 61.3\% (116.26 million ha) falls under rainfed farming. Marginal and small farmers constituting $80 \%$ of agricultural income group still depend on rainfed farming (Bhakar et al., 2008)

The degree to which rainfall amounts vary across an area or through time is an important characteristic of the climate of an area. This subject area in meteorology/climatology is called "rainfall variability." There are two types or components of rainfall variability, areal and temporal. Rainfall is one of the climatic variables that affect both the spatial and temporal patterns on water availability 
(De Luis et al., 2000; Kampata et al., 2008; Ngongordo, 2006).

\section{Materials and Methods}

\section{Study area}

Andhra Pradesh is the fifth largest state in India both in terms of area as well as population. The state is regarded as the 'granary' of the south. The state of Andhra Pradesh is divided into two geographical regions, viz., Coastal Andhra and Rayalaseema regions. Among the two regions, the present study is confined to Rayalaseema region. The region by its location extends approximately from $13^{\circ} 62^{\circ}$ North Latitude and $79^{\circ} 42^{\prime}$ East Longitude. It includes within its fold of four districts, Anantapur, Chittoor, Kadapa and Kurnool.

Rayalaseema receives more rainfall from south-west monsoon than the northeast monsoon. The average annual rainfall is hardly $672 \mathrm{~mm}$. South-west monsoon spreads from early June till the end of September. The north-east monsoon is generally from October to December.

\section{Data collection}

The meteorological data of rainfall required for the analysis was collected during period of 1989-2018 from Central Research Institute for Dryland Agriculture, Hyderabad. The weather data was compiled in the Excel sheet and Error Checking was done by different filters using the general range of the parameters.

The amount of rainfall collected by a given rain gauge in $24 \mathrm{hrs}$ is known as daily rainfall $(\mathrm{mm}$ or $\mathrm{cm})$ and the amount collected in one year in known as annual rainfall. The mean of the annual rainfall over of 30 years (in India) is known as mean annual rainfall (average annual rainfall or normal annual rainfall).
Mean Annual Rainfall $=$ Total Rainfall $/$ number of years

Standard deviation is the square root of the mean of the squares of deviations of the rainfall value from the arithmetic mean of all such rainfall. It is a measure of variability or the scatter or the dispersion about the mean value. It is given by the following formula.

$S D(\sigma)=\sqrt{\frac{\sum(X-\bar{X})^{2}}{n-1}}$

$\mathrm{X}=$ Rainfall $\bar{X}=$ Mean rainfall $\mathrm{n}=$ number of years

Assessment of rainfall variability through Coefficient of variation (CV \%) appears to be simple. CV is defined as the Standard deviation divided by the mean value of rainfall. It shows the variability of rainfall in percentage.

$$
\mathrm{CV} \%=\frac{\text { Standard Deviation }}{\text { Mean }} \times 100
$$

The greater the CV, the lesser the dependability of receiving rainfall.

\section{Results and Discussion}

Monthly and annual rainfall variability in area of Rayalaseema of Andhra Pradesh

The monthly and annual rainfall of all 4 districts of Rayalaseema for different months of the data for the period (1989 - 2018) was analyzed. Also, the decadal average rainfall as well as standard deviation (SD) and coefficient of variation $(\mathrm{CV})$ are worked out and the results are discussed.

Kadapa is located on $14^{0} 46^{\prime} \mathrm{N}$ latitude and $78^{0} 82^{\prime} \mathrm{E}$ longitude and surrounded by three districts of Andhra Pradesh i.e. Chittoor, Kurnool and Ananthpur (Fig. 1). On the perusal of table 1 , the observed average 
rainfall for a period of 1989-2018 was 823.02 $\mathrm{mm}$. The minimum \& maximum rainfall was $3.98-164.23 \mathrm{~mm}$ in the month of February\& October respectively. The calculated value of standard deviation (SD) was 193.09 and coefficient of variation (CV) value $23.46 \%$ during study period (1989-2018) in Kadapa district.

Ananthpur is located on $14^{0} 68^{\prime} \mathrm{N}$ latitude and $77^{\circ} 60^{\prime} \mathrm{E}$ longitude and surrounded by three districts of Andhra Pradesh i.e. Kurnool, Kadapa and Chittoor. On the perusal of table 1 , the observed average rainfall for a period of 1989-2018 was $557.32 \mathrm{~mm}$. The minimum \& maximum rainfall was $1.17-136.62 \mathrm{~mm}$ in the month of February \& September respectively. The calculated value of standard deviation (SD) was 170.05 and coefficient of variation (CV) value $30.51 \%$ during study period (1989-2018) in Ananthpur district (Fig. 2).

Figure 3 shows that the variation of rainfall for period (1989-1998) is $578.75 \mathrm{~mm}$ (minimum), $1314.27 \mathrm{~mm}$ (maximum) and average rainfall $854.28 \mathrm{~mm}$. The coefficient of variation for the period is $22.74 \%$. The minimum, maximum and mean value of rainfall for the period (1999-2008) is 440.31 $\mathrm{mm}, \quad 1201.08 \mathrm{~mm}$ and $778.82 \mathrm{~mm}$ respectively. CV value for a period is $31.01 \%$. From the Figure 3, its respectively thus varies of rainfall for a period of (2009-2018) is $628.96 \mathrm{~mm}$ (minimum), $1028.12 \mathrm{~mm}$ (maximum) and mean rainfall value 834.92 $\mathrm{mm}$. The CV value for the study period is $14.69 \%$. A similar trend was observed by other authors Srivastava and Chaudhary (1998) and Swetha et al., (2015).

Figure 4, show that the variation of rainfall for period (1989-1998) is $418.64 \mathrm{~mm}$ (minimum), $910.87 \mathrm{~mm}$ (maximum) and average rainfall $577.83 \mathrm{~mm}$. The coefficient of variation for the period is 23.78. The minimum, maximum and mean value of rainfall for the period (1999-2008) is 264.8 $\mathrm{mm}, 989.8 \mathrm{~mm}$ and $566.35 \mathrm{~mm}$ respectively. $\mathrm{CV}$ value for a period is $36.16 \%$. From the Figure 4, its respectively thus varies of rainfall for the period $(2009-2018)$ is 321.3 $\mathrm{mm}$ (minimum), $885.8 \mathrm{~mm}$ (maximum) and mean rainfall value $524.80 \mathrm{~mm}$. The $\mathrm{CV}$ value for the study period is $33.38 \%$.A similar trend was observed by other authors Chaudhary and Sastri (1999) and Mondal and Khare (2015).

Chittor is located on $13^{0} 47^{\prime} \mathrm{N}$ latitude and $78^{0}$ 83' E longitude and surrounded by three districts of Andhra Pradesh i.e. Kadapa, Kurnool and Ananthpur. On the perusal of table 2, the observed average rainfall for a period of 1989-2018 was $956.09 \mathrm{~mm}$. The minimum \& maximum rainfall was 7.23$176.40 \mathrm{~mm}$ in the month of January\& October respectively. The calculated value of standard deviation (SD) was 217.39 and coefficient of variation $(\mathrm{CV})$ value $22.74 \%$ during study period (1989-2018) in Chittor district.

Kurnool is located on $15^{\circ} 64^{\prime} \mathrm{N}$ latitude and $78^{0} 11^{\prime} \mathrm{E}$ longitude and surrounded by three districts of Andhra Pradesh i.e. Kadapa, Chittor and Ananthpur. On the perusal of table 2, the observed average rainfall for a period of 1989-2018 was $725.10 \mathrm{~mm}$. The minimum \& maximum rainfall was 3.62$144.49 \mathrm{~mm}$ in the month of February\& September respective ely. The calculated value of standard deviation (SD) was 143.03and coefficient of variation $(\mathrm{CV})$ value $19.72 \%$ during study period (1989-2018) in Kurnool district

Figure 5, show that the variation of rainfall for period (1989-1998) is $745.6 \mathrm{~mm}$ (minimum), $1529.7 \mathrm{~mm}$ (maximum) and average rainfall $1065.45 \mathrm{~mm}$. The coefficient of variation for the period is $21.82 \%$. The minimum, maximum and mean value of rainfall for the period (1999-2008) is 639.18 $\mathrm{mm}, \quad 1469.46 \mathrm{~mm}$ and $901.42 \mathrm{~mm}$ 
respectively. $\mathrm{CV}$ value for a period is $28.17 \%$. From the Figure 5, its respectively thus varies of rainfall for a period of (2009-2018) is $796.20 \mathrm{~mm}$ (minimum), $1158.47 \mathrm{~mm}$ (maximum) and mean rainfall value 901.38 $\mathrm{mm}$. The CV value for the study period is 13.05. A similar trend was observed by other authors Srivastava and Chaudhary (1998) and Swetha et al., (2015).

Table.1 Rainfall results of Kadapa and Ananthpur for the period 1989-2018

\begin{tabular}{|c|c|c|c|c|c|c|}
\hline \multirow{2}{*}{ MONTH } & \multicolumn{3}{|c|}{ KADAPA } & \multicolumn{3}{c|}{ ANANTHPUR } \\
\cline { 2 - 7 } & Mean & SD & CV (\%) & Mean & SD & CV (\%) \\
\hline JAN & 4.66 & 5.59 & 119.95 & 2.48 & 5.52 & 222.58 \\
\hline FEB & 3.98 & 7.64 & 191.95 & 1.17 & 1.61 & 137.60 \\
\hline MAR & 10.83 & 14.09 & 130.10 & 8.74 & 20.06 & 229.52 \\
\hline APR & 16.60 & 16.03 & 96.56 & 16.40 & 17.41 & 106.15 \\
\hline MAY & 74.56 & 60.65 & 81.34 & 53.26 & 37.52 & 70.44 \\
\hline JUN & 60.83 & 60.05 & 98.71 & 70.85 & 55.26 & 77.99 \\
\hline JUL & 127.55 & 67.80 & 53.15 & 71.59 & 52.84 & 73.80 \\
\hline AUG & 113.51 & 55.85 & 49.20 & 92.56 & 61.61 & 66.56 \\
\hline SEP & 130.75 & 58.28 & 44.57 & 136.62 & 84.36 & 61.74 \\
\hline OCT & 164.23 & 99.69 & 60.70 & 94.50 & 64.89 & 68.66 \\
\hline NOV & 97.48 & 76.83 & 78.81 & 30.42 & 29.55 & 97.14 \\
\hline DEC & 35.37 & 33.60 & 94.99 & 6.70 & 11.59 & 172.98 \\
\hline Annually(30yrs) & $\mathbf{8 2 3 . 0 2}$ & $\mathbf{1 9 3 . 0 9}$ & $\mathbf{2 3 . 4 6}$ & $\mathbf{5 5 7 . 3 2}$ & $\mathbf{1 7 0 . 0 5}$ & $\mathbf{3 0 . 5 1}$ \\
\hline
\end{tabular}

Table.2 Rainfall results of Chittoor and Kurnool for the period 1989-2018

\begin{tabular}{|c|c|c|c|c|c|c|}
\hline MONTH & \multicolumn{3}{|c}{ CHITTOOR } & \multicolumn{3}{c|}{ KURNOOL } \\
\cline { 2 - 6 } & Mean & $\mathbf{S D}$ & $\begin{array}{c}\mathbf{C V} \\
\mathbf{( \% )}\end{array}$ & Mean & $\mathbf{S D}$ & $\begin{array}{c}\mathbf{C V} \\
\mathbf{( \% )}\end{array}$ \\
\hline JAN & 7.23 & 12.60 & 174.27 & 3.69 & 6.95 & 188.35 \\
\hline FEB & 8.35 & 14.86 & 177.96 & 3.62 & 6.73 & 185.91 \\
\hline MAR & 11.27 & 17.58 & 155.98 & 10.27 & 21.77 & 211.97 \\
\hline APR & 25.75 & 21.14 & 82.09 & 19.91 & 13.71 & 68.85 \\
\hline MAY & 67.98 & 49.01 & 72.09 & 62.64 & 43.54 & 69.50 \\
\hline JUN & 74.60 & 56.67 & 75.96 & 90.59 & 44.48 & 49.10 \\
\hline JUL & 109.17 & 48.93 & 44.82 & 140.08 & 64.04 & 45.71 \\
\hline AUG & 158.57 & 95.48 & 60.09 & 131.33 & 69.30 & 52.76 \\
\hline SEP & 121.20 & 46.36 & 38.25 & 144.49 & 57.12 & 39.53 \\
\hline OCT & 176.40 & 72.17 & 40.91 & 105.80 & 89.70 & 84.78 \\
\hline NOV & 151.86 & 104.78 & 68.99 & 32.27 & 24.08 & 74.62 \\
\hline DEC & 74.46 & 60.25 & 80.91 & 5.13 & 11.85 & 230.99 \\
\hline $\begin{array}{c}\text { Annually } \\
\text { (30yrs) }\end{array}$ & $\mathbf{9 5 6 . 0 9}$ & $\mathbf{2 1 7 . 3 9}$ & $\mathbf{2 2 . 7 4}$ & $\mathbf{7 2 5 . 1 0}$ & $\mathbf{1 4 3 . 0 3}$ & $\mathbf{1 9 . 7 2}$ \\
\hline
\end{tabular}


Table.3 Annual rainfall results of all Districts for the period 1989-2018

\begin{tabular}{|c|c|c|c|}
\hline DISTRICT & Mean & SD & CV \\
& & & $(\boldsymbol{\%})$ \\
\hline Kadapa & 823.02 & 193.09 & 23.46 \\
\hline Ananthpur & 557.32 & 170.05 & 30.51 \\
\hline Chittor & 956.09 & 217.39 & 22.74 \\
\hline Kurnool & 725.10 & 143.03 & 19.72 \\
\hline
\end{tabular}

Fig.1 Location map of study area

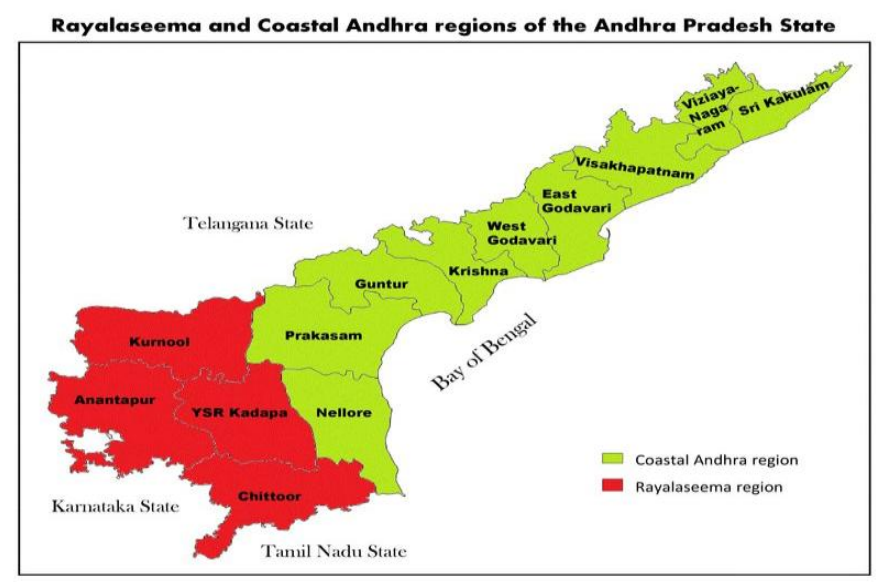

Fig.2 Methodology flow chart

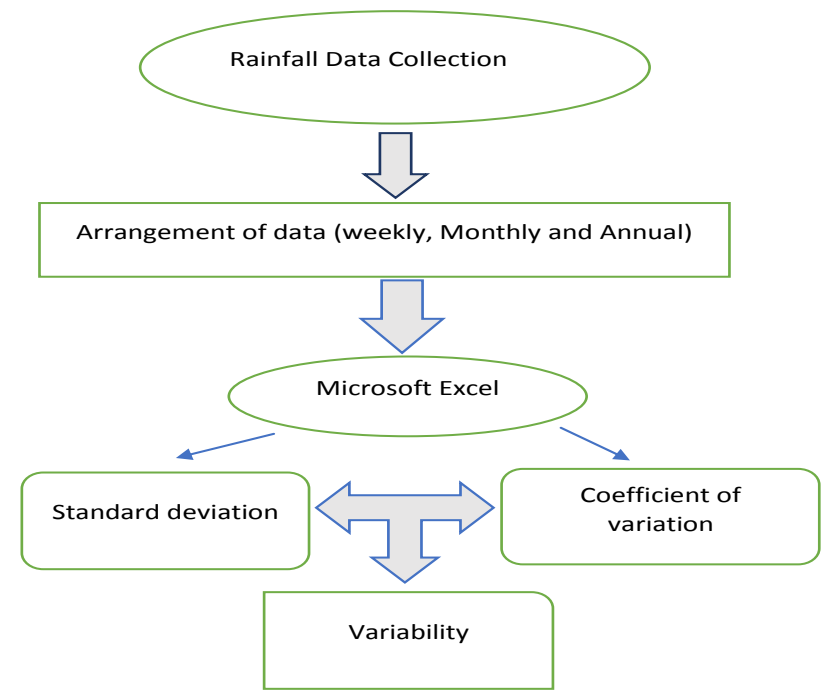


Fig.3 Decadal rainfall $(\mathrm{mm})$ and its variability at Kadapa

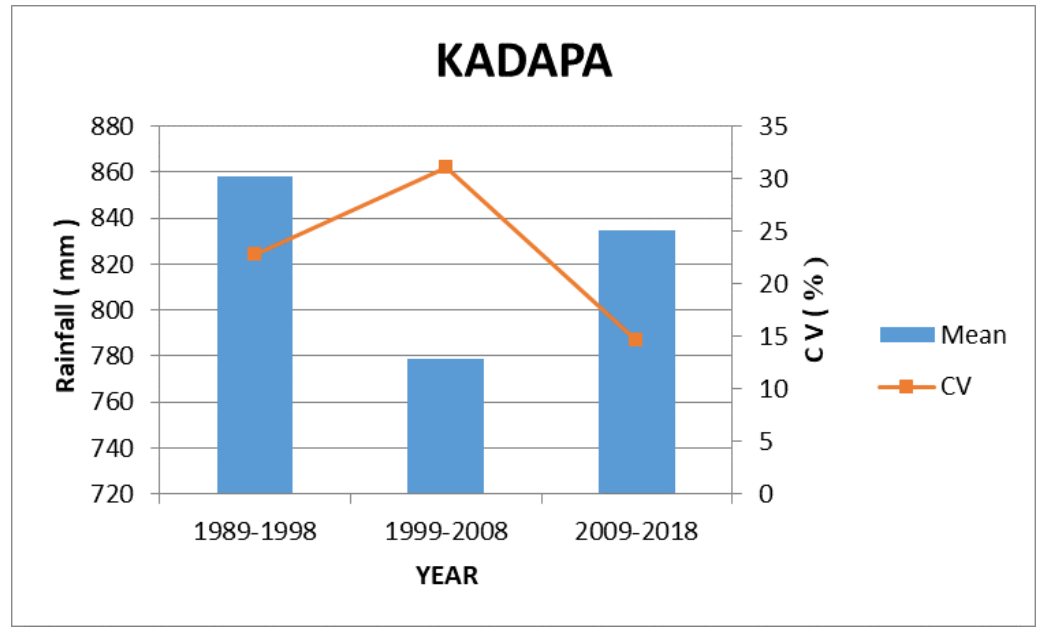

Fig.4 Decadal rainfall (mm) and its variability at Ananthpur

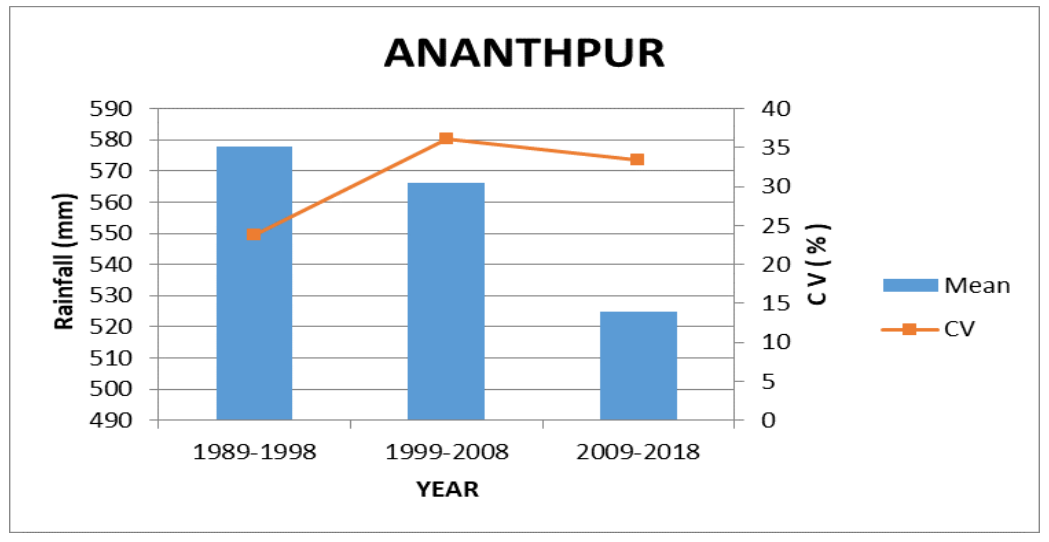

Fig.5 Decadal rainfall (mm) and its variability at Chittor

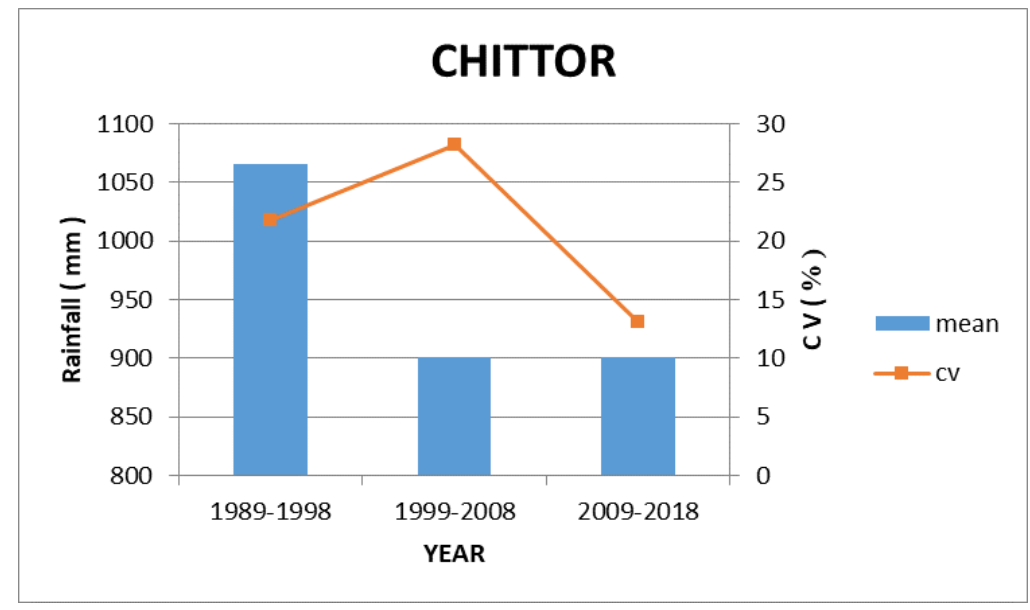


Fig.6 Decadal rainfall $(\mathrm{mm})$ and its variability at Kurnool

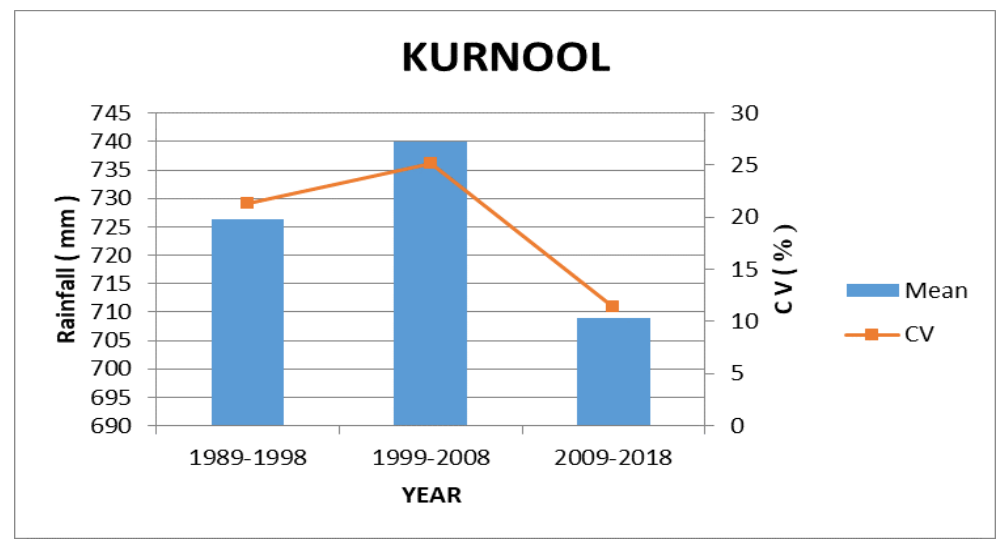

Figure 6 show that the variation of rainfall for period (1989-1998) is $551.98 \mathrm{~mm}$ (minimum), $1034.37 \mathrm{~mm}$ (maximum) and average rainfall $726.34 \mathrm{~mm}$. The coefficient of variation for the period is $21.36 \%$. The minimum, maximum and mean value of rainfall for the period (1999-2008) is $483.56 \mathrm{~mm}, 1089.93$ $\mathrm{mm}$ and $739.92 \mathrm{~mm}$ respectively. CV value for a period is $25.18 \%$. From the Figure 6, its respectively thus varies of rainfall for a period of (2009-2018) is $537.73 \mathrm{~mm}$ (minimum), $851.12 \mathrm{~mm}$ (maximum) and mean rainfall value $709.05 \mathrm{~mm}$. The CV value for the study period is 11.45. A similar trend was observed by other authors Srivastava and Chaudhary (1998) and Swetha et al., (2015)

Table 3 showed that Chittor district the average annual rainfall is higher $(956.09 \mathrm{~mm})$ followed by Kadapa $(823.02 \mathrm{~mm})$ and Kurnool (725.10 $\mathrm{mm})$. The mean annual rainfall is lowest at Ananthpur $(557.32 \mathrm{~mm})$. When the $\mathrm{CV}$ for the annual rainfall was examined, it was found be the least at Kurnool (19.72\%) followed by Chittor (22.74 $\%)$. At Kadapa it was $23.46 \%$ and at Ananthpur it was the highest (30.51\%).

In conclusion it was found that the annual rainfall is higher at Chittor district followed by Kadapa and Kurnool. The mean annual rainfall is lowest at Ananthpur. When the CV for the annual rainfall or Rainfall variability was examined, it was found be the least at Kurnool followed by Chittor and Kadapa. At Ananthpur it was the highest. The highest variability in rainfall observed in Ananthpur is another confirmation of climate change.

\section{Acknowledgement}

The Authors are thankful to Department of Environmental Sciences and Natural Resource Management, SHUATS, Prayagraj, for taking their keep interest and encouragement to carry out the research work.

\section{References}

Biradar, Vishwanath, Biradar, Baswaraj and Arunkumar, B. (2011). Annual and seasonal rainfall variability of Bidar taluka (Karnataka). Internat. J. agric. Sci., 7(1): 183-186.

De Luis, M, Raventos J, Gonzalez-Hidalgo JC, Sanchez JR, Cortina J. 2000. Spatial analysis of rainfall trends in the region of Valencia (East Spain). International Journal of Climatology 20(12): 1451-1469.

Gare, B.N., More, S.M., Jadhav, A.S., Burli, A.V., Mokashi, D.D. 2000. Rainfall variability analysis at Gadhinglaj. Journal of Maharashtra Agricultural 
Universities. 25(2): 198-20

Mapande, T., Amin and Reason, C.J.C. 2005.Interannual rainfall variability over Western Tanzania. International Journal of Climatology 25:1355-1368.

Mehta, D.R., Kalola, A.D., Saradava, D.A., Yusufzai, A.S. 2002. Rainfall variability analysis and its impact on crop productivity - a case study. Indian Journal of Agricultural Research. 36(1): 29-33.
Sarmah.(2013) investigated on the basis of 27 years weather data of Lakhimpur Journal of agrometeorology 15 (Special Issue-II (December 2013)):247-250

Upendra S., Agrawal, K.K., Gupta, V.K. and Shankar,U.1993. Commencement of rainy season and rainfall analysis for Jabalpur region. JNKVV Research Journal 27(1):118-121News. 43(2):5357.

\section{How to cite this article:}

Kanaparthi Narasimhareddy, Abhishek James and Shweta Gautam. 2020. Rainfall Variability in Rayalaseema Region of Andhra Pradesh. Int.J.Curr.Microbiol.App.Sci. 9(12): 124-131. doi: https://doi.org/10.20546/ijcmas.2020.912.016 